"Widening fiscal deficit in Maharashtra state: causes and concerns"

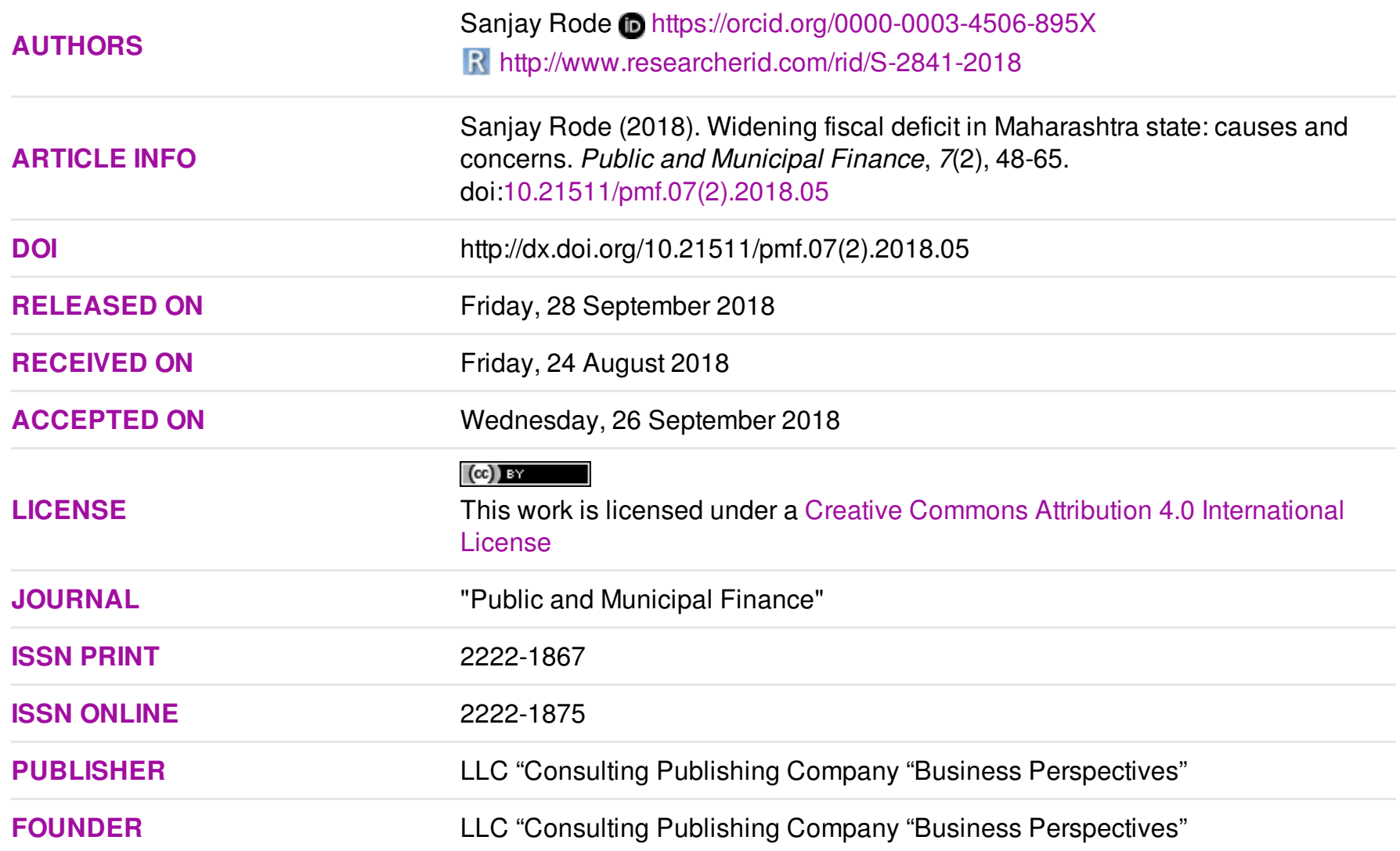

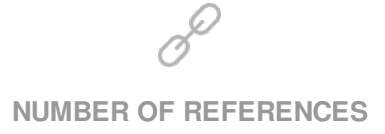

14

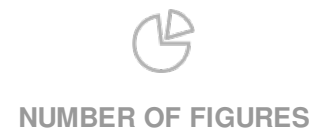

2
NUMBER OF TABLES

12

(C) The author(s) 2021. This publication is an open access article. 


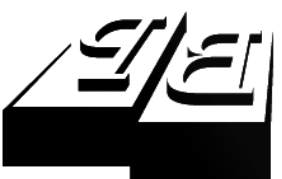

BUSINESS PERSPECTIVES

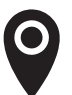

LLC “CPC "Business Perspectives" Hryhorii Skovoroda lane, 10, Sumy, 40022, Ukraine

www.businessperspectives.org
Received on: $24^{\text {th }}$ of August, 2018 Accepted on: $26^{\text {th }}$ of September, 2018

(C) Sanjay Rode, 2018

Sanjay Rode, Ph.D, Assistant Professor, Aurobindo, Vidyavihar (E) Mumbai, India

\section{WIDENING FISCAL DEFICIT IN MAHARASHTRA STATE: CAUSES AND CONCERNS}

\begin{abstract}
Maharashtra is highly urbanized and economically developed state in India. But now the growth rate is declining, and debt burden has increased in the state. CAGR has been used to examine the impact of FRBM act on fiscal deficit in the state. The RBI data from 1991 to 2016 show that the primary and fiscal deficit is increasing fast. The revenue and capital expenditure are increasing after 2003 FRBM act. The debt burden has increased in the state due to interest payment, pension liabilities, seventh pay commission to state employees, farm loan waiver scheme and infrastructure projects. State government took loans from different sources to finance its capital expenditure. The least square regression result shows that development expenditure in the state has declined very fast. The expenditure on health, education and social welfare of scheduled caste and tribe has declined in the state over the period of time. Government must improve revenue and capital receipts within the short period. Efforts must be made to reduce the debt burden on the state. Therefore, a number of alternative policies are required to improve revenue and capital receipts. State government must increase taxes on electronic and tobacco-related products. Taxes must be increased on commercial vehicles, luxury hotels, entry tax at hill stations, malls and purchase of diamonds and gold, petrol and diesel. Such sources will increase tax revenue to state government and fiscal deficit can be reduced to some extent.
\end{abstract}

Keywords revenue, healthcare, nutrition, budget

JEL Classification $\quad \mathrm{H} 6, \mathrm{H} 76, \mathrm{R} 28$

\section{INTRODUCTION}

The fiscal deficits are widening of state governments from 2.7 per cent to 3.1 in the current year in India. It has re-emerged as a cause of concern for the Indian economy, because GFD-GDP ratio crossed the threshold for the third consecutive year (RBI, 2018). Maharashtra is one of the more progressive states of Indian federation (Pethe \& Lalvani, 2005). Fiscal deficit in Maharashtra state is increasing fast, because of farm loan waiver and seventh pay hikes of employees. The non-productive expenditure is reducing the capital expenditure of the state. In the state, urbanization is increasing very fast. Not only people from rural area but those from all over India are migrating to the state. Therefore, overpopulation affects the existing infrastructure facilities in the state. There is huge demand for housing but housing is not affordable to poor people.

The state government is not investing enough in housing for poor people. It has resulted in slums and encroachment upon private and public land. The slums are found near railway stations, top of dangerous hills, below high tension electric wires, pipelines, gardens, etc. Slums have inadequate coverage of sanitation, water supply, electricity, health care and roads. It has affected on human resource development in the state.

Youths are not provided with skilled education in the state. State has maximum employment opportunities, but the youths do not receive 
the job oriented education. They do not get the jobs and higher income. The state has not adopted the labor friendly policies and standards; has sharply reduced the expenditure on labor and labor welfare schemes over the period of time. The state government is not spending enough resources on innovations of science and technology. Most of the administrative services are now available on online basis. But the state government is not able to provide all administrative services online to people all over the state. It increases the delay and problems in provisions of public services to people in the state. People in the state are vising government offices for various issues. In government offices, maximum work is still done on manual basis and whole administration is busy in finding various files. Providing online records and survey is a primary responsibility of the state. But funds are not available to adopt scientific methods and technology for every socio-economic issue. State has reduced its role in water and soil conservation. Earlier governments have spent maximum amount of money for water and soil conservation. State has reduced its role in minor and major irrigation projects due to high corruption. Each village required the water, soil conservation scheme, but state government has no resources for such schemes. Most of water conservation schemes are announced, but resources are not provided by state. Now state more relies on private participation as far as water conservation is concerned. State is suffering from high water, air, and soil pollution. Almost all rivers are highly polluted and this affects the agriculture production and people health. Soil quality is degraded due to multiple cropping pattern, insecticides, pesticides, use of polluted water for irrigation. In the state, industries, vehicles, urbanization is polluting air and it is affecting severely the people health.

Health care infrastructure is inadequate in the state. All the health care facilities are overcrowded. Most of the health care job vacancies are not filled. Doctors are not ready to serve rural communities. The is due to remuneration and health care infrastructure in rural areas. Therefore, people in rural areas do not get quality health care in the state. In urban area, all health care facilities are overcrowded and health care is not provided efficiently to people. There are inequalities and inefficiencies in health care services in the state. Since independence, state government encouraged the small scale industries for employment and production. But now government does not provide any benefit and subsidy or include such industries in the planning. Such industries are located at grass root level and providing employment to rural people. But state government has reduced the spending on such small scale industries. Investment in roads, ports has also been reduced by government. There is a direct relationship between public expenditure and economic development (Agbonkhese \& Asekome, 2014). But state has limited funds for various public services. In the state, maximum infrastructure services are brought under public private partnership. Maximum roads are built by private contractors and toll tax is charged for a long period of time. It is an economic burden on people of the state. Education sector is a backbone of state, but many self-financing schools, colleges, private universities are established. The role of state has reduced in financing of primary, secondary and higher education. The quality education is not provided to youths in the state. Youths are not empowered for self-, placement based or industry based employment. Private education is highly expensive for poor people in the state. This affects education and income generating activities of poor people in the long term.

Health care services are almost privatized in the state. Only few hospitals are getting the government funding in the state. Few hospitals in rural and urban areas receive grants from the state. It affects quality health care provided to rural and urban areas in the state. Agriculture is a backbone of state over the period of time. The state has reduced the investment in agriculture. Agriculture production and growth are negative in the state. Farmers invest in agriculture, but due to drought and unseasonal rain, the farmers earn huge losses in the state. They fall in debt trap where they continuously demand loan waiver schemes. Such loan waiver scheme is an additional burden on the state finances. State government spend very less funds on water, soil conservation, warehousing, commodity markets and information of prices to farmers. Farmer's suicides are regularly observed 
in the state. The main objective of this research paper is to understand the nature of public finance in the state, and get an idea about the link between non-productive expenditure and capital expenditure of the state. The first part of the research paper explains data and methodology. The second part accounts for revenue receipts and expenditure, capital receipts and expenditure before and after the FRBM Act. The last part of this research paper presents the regression results and policy implication.

\section{DATA}

Secondary data of Maharashtra government budgets have been collected from 1991 till 2016. The secondary data about Maharashtra State budgets from 1991-1992 till 2015-2016 are also available on the RBI website. The budgets of each year comprise revenue receipts and expenditure, capital receipts and expenditure. 1991 to 2016 budgets of Maharashtra state have been analysed.

\section{METHODOLOGY}

For data analysis, Compound Annual Growth Rate (CAGR) has been used. The entire data within two periods were divided. That is before and after the Fiscal Regulatory and Budgetary Management Act (FRBMA). The FRBM act of 2003 has changed expenditure pattern of the state and central government. The authors have calculated the annual compound growth rate of different subheads of revenue receipts and expenditure, capital receipts and expenditure. Such method helped to understand the growth of subheads before and after the FRBM Act.

\subsection{Compound growth rate is explained as follows:}

$$
Y_{t}=a b^{t},
$$

where $Y_{t}$ - estimated income or expenditure, $t$ year, $a$ and $b$-parameters to be estimated.

$$
\log y_{t}=\log a+t \log b+\log u_{t} .
$$

Above equation is estimated by the ordinary least square (OLS) method, compound growth rate $(g)$ is then estimated by the identity given in equation as follows.

$$
g=(\hat{b}-1) \cdot 100
$$

where $g$ - estimated compound growth rate in per cent and

$$
\hat{b}=\operatorname{anti} \log b .
$$

Ordinary least square regression method has been used to understand the relationship of revenue and capital receipts and expenditure with subheads. In order to examine the effects of FRBM Act on revenue receipts and expenditure, capital receipts and expenditure, the dummy variable approach method was used.STATA @11 has been used for data analysis.

\subsection{Economic model:}

The separate equation for revenue receipts, revenue expenditure, capital receipts and capital expenditure of state over the period of time has been developed. They are explained as follows:

$$
R R=T R+N T R,
$$

where $R R$ means Revenue receipts. The $T R$ is defined as Tax revenue. The NTR is explained as Non Tax revenue.

$$
T R=S O T R+S C T,
$$

$T R$ is defined as Tax revenue of state. The SOTR is explained as State's Own Tax Revenue. The SCT means Share in Central Taxes of Maharashtra.

$$
S O T R=T O I+T P C T+T C S,
$$

where SOTR is State's Own Tax Revenue and TOI means Taxes on Income. The TPCT is defined as Taxes on Property and Capital Transactions, whereas TCS is defined as Taxes on Commodities and Services.

$$
N T R=S O N T R+G C,
$$

where NTR means Non tax revenue whereas SONTR is defined as State's Own Non-Tax Revenue. $G C$ is Grants from the Center. 


$$
R E=D E+N D E+G A C,
$$

where $R E$ is defined as Revenue expenditure of the state and $D E$ means Development expenditure. $N D E$ is defined as Non-development expenditure of Maharashtra, whereas $G A C$ means Grants in aid contributions of the state.

$$
D E=S S+E S,
$$

where $D E$ means Development expenditure of Maharashtra state. It is further categorized as $S S$ - Social services and ES - Economic services.

$$
\begin{aligned}
& N D E=O S+F S+I P S D+ \\
& +A S+P e+M G S,
\end{aligned}
$$

where $N D E$ is defined as Non-development expenditure and $O S$ is Organs of State. The $F S$ is Fiscal services, whereas IPSD is Interest Payments and Servicing of Debt of the state over the period of time. $A S$ is defined as Administrative Services of the state in urban and rural areas. $P e$ is Pensions and $M G S$ is Miscellaneous General Services of the state government in the past.

$$
\begin{aligned}
& C E t=E D+I D+L A C+R L A+ \\
& +I S S+C F+S S P F+R F+D A+ \\
& +S M+A C F+R .
\end{aligned}
$$

$C E$ in defined as Capital expenditure and $E D$ is an External Debt in the state. $I D$ means Internal debt and $L A C$ is Loans and Advances from the Center. Maharashtra state took loan from internal and external sources over the period of time. RLA is defined as Recovery of Loans and advances. $I S S$ is further defined as Inter-State Settlement, whereas $C F$ means Contingency Fund with state government. SSPF is defined as Small Savings and Provident Funds contribution of the state government. $R F$ means Reserve Funds and $D A$ is Deposits and Advances State uses reserve funds during natural calamities. $S M$ is defined as Suspense and Miscellaneous, whereas $A C F$ means Appropriation to Contingency Fund. Lastly, the MCR is Miscellaneous Capital Receipts, whereas $R$ means Remittances.

$$
\begin{aligned}
& C E t=T C O+D I D+R L C+L A S+I S S+ \\
& +C F+S S P F+R F+D A+S M+A C F+R,
\end{aligned}
$$

where $C E$ means Capital expenditure of the state. $T C O$ is Total Capital Outlay. DID is Discharge of Internal Debt, whereas $R L C$ is Repayment of Loans to the Center. State government repays the past loans regularly. $L A S$ is Loans and Advances by the State and $I S S$ is Inter-State Settlement. $C F$ is Contingency Fund and SSPF is Small Savings and Provident Funds. $R F$ is Reserve Funds with the state government. $D A$ has been defined as Deposits and Advances and $S M$ means Suspense and Miscellaneous. Lastly, $A C F$ is Appropriation to Contingency Fund and $R$ is Remittances.

$$
T C O=D E+N D E,
$$

where the $T C O$ means Total Capital Outlay and it is equal to $D E$ (Developmental expenditure) and $N D E$ (Non-Developmental expenditure).

\subsection{The Net State Domestic Product and Per capita NSDP of the state}

Since liberalization, there is growth of Net State Domestic Product (NSDP). The state has observed growth in production of goods and services. The money value of goods and services for various years is presented in Figure 1.

The NSDP and Per capita NSDP of the state have increased from 1991 till 2014-2015. NSDP has increased after liberalization and globalization period. In 1990-1991, NSDP and PCNSDP at current and constant prices were below Rs. 2 lakh crore. During 2004-2005, NSDP at current and constant prices is observed as Rs. 4 lakh crore. In the period of 2011-2012, NSDP at current and constant prices was observed around 11 lakh crore. NSDP at current prices has increased very fast after 2008-2009. The economy of Maharashtra is now integrated into world economy. In 2014-2015, it amounted to Rs. 16 lakh crore, whereas PCNSDP at current prices was more than Rs 13 lakh crore in 2014-2015. NSDP and PCNSDP at constant prices were observed as below Rs 2 lakh crore in 2014-2015. The population of the state has increased over the period of time. NSDP at current and constant prices is increasing fast in the state because of high manufacturing and services sector contribution. The state more depends on services sector for economic growth. High debt burden was found along with the increase in the state 


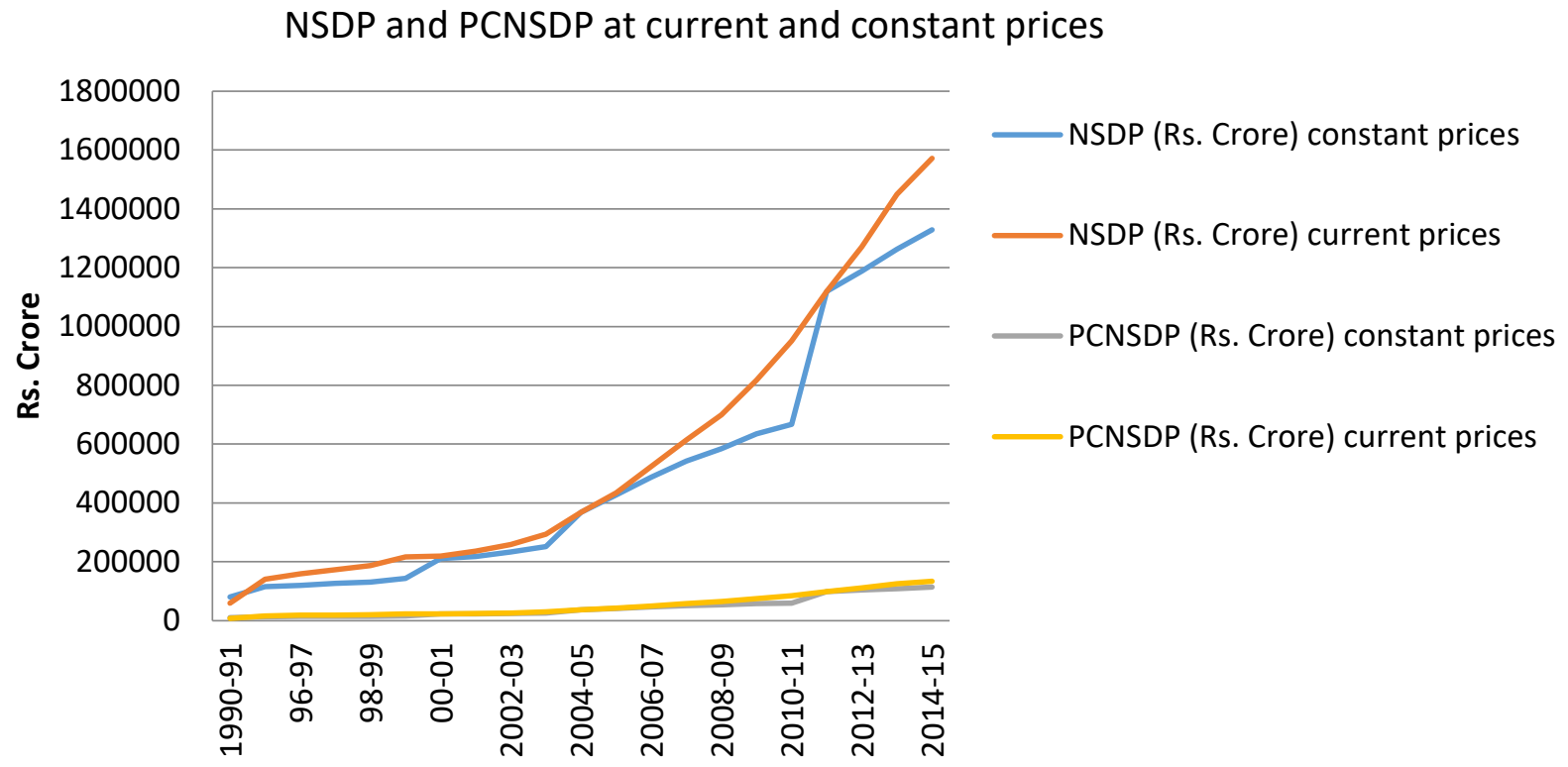

Figure 1. NSDP and Per capita NSDP of the state (Rs. Crore)

domestic product. It is explained as follows.

\subsection{Deficits in Maharashtra}

Maharashtra is a highly progressive state in India, but now it witnesses a high revenue deficit. In 2003, the central government enacted the Fiscal Responsibility and Budget Management Act (FRBMA). As mentioned earlier, the state also enacted Fiscal Responsibility Acts (FRA) on the recommendation of the Twelfth Finance Commission (Chakraborty, 2017). The revenue, primary, budgetary and fiscal deficits are presented in Figure 2.

Figure 2 shows that revenue deficit was 0.4 per cent in 1991-1992. After the liberalization peri- od, the revenue deficit has increased in the state. It was observed as 3.1 per cent in 2000-2001. The state had more revenue expenditure than revenue. In 2005-2006, it was 0.8 per cent. In 2013-2014, it was 0.2 per cent. The primary deficit was 1.8 per cent in 1991-1992. It was observed as 2.4 per cent in 2003-2004. The primary deficit has increased over the period of time. In 2007-2008, primary deficit was observed as 2.3 per cent. From 20122013 to 2014-2015, it was observed as 0.4 per cent. The budgetary deficit was 0.1 per cent in 1995 1996. In 2005-2006, it was observed as minus 1 per cent. From 2012-2013 to 2014-2015, the budgetary deficit is not observed at all. The fiscal deficit was 3.3 per cent in 1991-1992. In 1998-1999, the fiscal deficit was 3.8 per cent. It has slightly grown

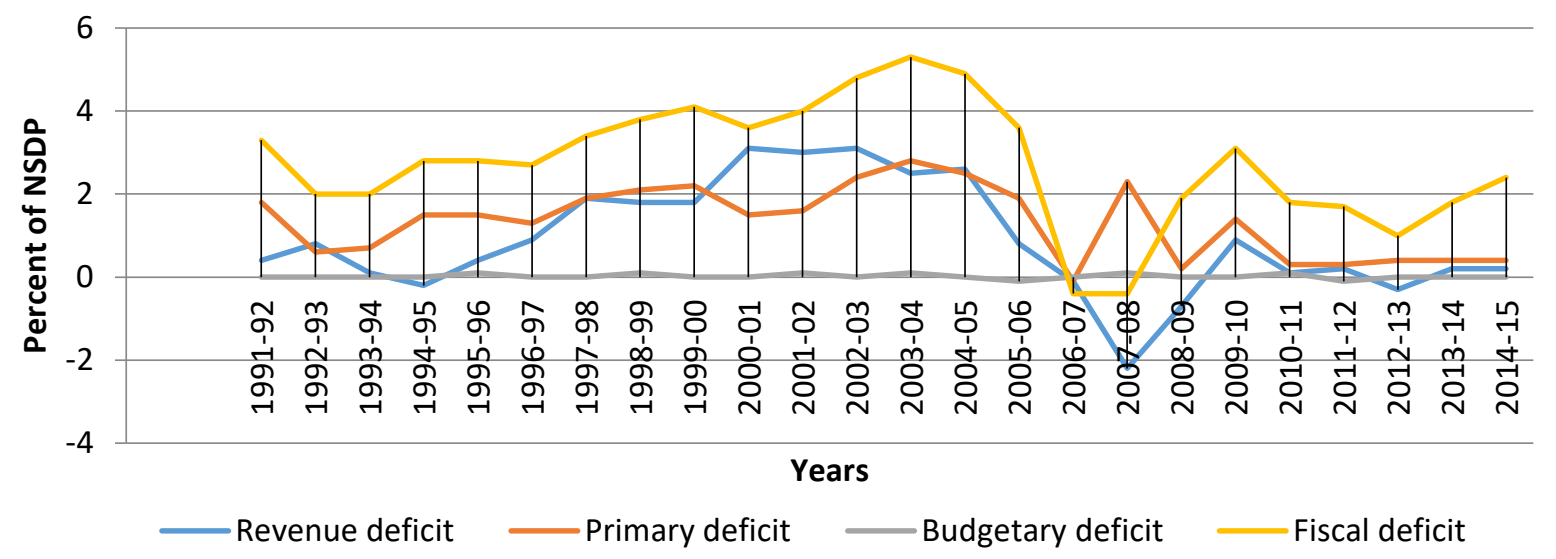

Figure 2. Revenue, primary, budgetary and fiscal deficits from liberalization era 
over the period of time. In 2002-2003, fiscal deficit was 4.8 per cent. In this period, the state had high revenue and capital expenditure. In 2003-2004, fiscal deficit was 5.3 per cent. High fiscal deficit was the major concern for the state. In 2006-2007, the fiscal deficit was -0.4 per cent. The state has reduced the fiscal deficit after the FRBM Act. In 2008-2009, fiscal deficit was -0.4 per cent. But again, the state has witnessed growing fiscal deficit. In 2008-2009, fiscal deficit was 1.9 per cent. In 2013-2014, fiscal deficit was 1.8 per cent. In 20142015 , fiscal deficit was 2.4 per cent. One can see that fiscal deficit has again increased for the state. The non-plan and non-productive expenditure is driving the growth of fiscal deficit in the state. The state government was not able to control its revenue and capital expenditure. this will be explained in more detail in the following paragraphs.

\subsection{The revenue receipts of the state}

The growth of revenue receipts of the state is explained in two periods (Table 1). The first period is explained as pre FRBM Act and post FRBM Act.

Table 1. Revenue receipts of the state government (per cent)

Source: Compiled based on the RBI data.

\begin{tabular}{l|c:c}
\hline \multicolumn{1}{c}{ Revenue receipts } & First period & $\begin{array}{c}\text { Second } \\
\text { period }\end{array}$ \\
\hline Total revenue & 11.98 & 14.35 \\
\hline Tax revenue & 10.89 & 14.38 \\
\hline State's own tax revenue & 12.6 & 13.76 \\
\hline Taxes on income & 14.63 & 5.44 \\
\hline Taxes on property and capital & 18.62 & 16.05 \\
transactions & 11.87 & 13.64 \\
\hline Taxes on commodities and & 7.91 & 8.82 \\
services & 7.74 & 5.9 \\
\hline Share in central taxes & 8.26 & -9.63 \\
\hline Non-tax revenue & 8.96 & -2.18 \\
\hline State's own non-tax revenue & -5.33 & -1.00 \\
\hline Interest receipts & 8.34 & 4.13 \\
\hline Dividends and profits & 11.84 & 16.48 \\
\hline General services & - & - \\
\hline Social services & 7.11 & 9.85 \\
\hline Fiscal services & 6.43 & 20.67 \\
\hline Economic services & & \\
\hline Grants from the center & & \\
\hline & & \\
\hline
\end{tabular}

Note: The first period is $1991-92$ to $2002-03$ and the second period is 2003-2004 to 2015-2016.

Tax revenue comprises state own tax revenue and share in central taxes. The tax revenue of the state government has increased in the first pe- riod. Earlier the CAGR was 10.89 per cent and in the second period, it is observed as 14.38 per cent. Tax revenue receipts have increased over the period of time in the state. State government imposed goods and services tax on various commodities. Therefore, a revenue receipt of the state government has increased over the period of time. State's own tax revenue has increased, CAGR was 12.6 per cent and it has increased to 13.76 per cent. State's own tax revenue has increased slightly because of taxes on property and capital transactions. But the income from taxes has declined from 14.63 per cent to 5.44 per cent. This may be because central government imposed direct tax on individual income. There was no slight change observed in taxes on commodities (11.87 per cent to 13.64 per cent) and services over the two periods. The taxes on commodities and services have also increased from the 20022013 period. Taxes on income have declined in the second period. The share in central taxes has increased slightly from 7.91 per cent to 8.82 per cent over the two periods. The share in central taxes has increased in the second period. This is because state is highly urbanized, it contributes more in economic activities. Therefore, the share in central taxes is more. The non-tax revenue has declined from 7.74 per cent to 5.9 per cent from the first to the second period. Non-tax revenue of the state government has declined over the period of time. The state has not given much importance to profit, dividends and interest payment receipts. The interest payment has sharply declined over the period of time. State has no surplus for many reasons. The receipts of state government are less and expenditure is more. Therefore, surplus has declined. The deficit does not generate any interest but state has to pay more interest. Therefore, dividends and profits have sharply declined in the second period. Revenue receipts from general services have declined and it has observed as half in the second period. The state's own tax revenue has declined from 8.26 per cent to 9.63 per cent over the period of time. This is mainly due to interest receipts, which declined from 8.96 per cent to 2.18 per cent over the two periods. The dividends and profits have declined from 8.34 per cent to 4.13 per cent over the two periods. The revenue from general services has declined from 8.34 per cent to 4.13 per cent over the two periods. The revenue receipts from social services have in- 
creased from 11.84 per cent to 16.48 per cent over the period of time. Revenue receipts from social services have increased sharply over the period of time. The state spends more resources on social services. It is observable from the data because such expenditure has increased over the period of time. Therefore, the revenue receipts from social services have also increased over the period of time. The revenue from economic services has increased from 7.71 per cent to 9.85 per cent over the period of time. The grants from central government have increased from 6.43 per cent to 20.67 per cent from the first to the second period.

Table 2. Maharashtra and revenue expenditure (per cent)

Source: Compiled based on the RBI data.

\begin{tabular}{l|c:c}
\hline \multicolumn{1}{c}{ Particulars } & $\begin{array}{c}\text { First } \\
\text { period }\end{array}$ & $\begin{array}{c}\text { Second } \\
\text { period }\end{array}$ \\
\hline Total expenditure & 12.5 & 4.88 \\
\hline Developmental expenditure & 10.28 & 14.93 \\
\hline Social services & 12.44 & 14.51 \\
\hline Economic services & 7.37 & 16 \\
\hdashline Non-developmental & 16.03 & 10 \\
expenditure & 12.05 & 14.01 \\
\hdashline Organs of state & 30.69 & -3.5 \\
\hline Fiscal services & 14.92 & 9.71 \\
\hdashline Interest payments and servicing & 10.43 & 13.94 \\
Of debt & 11.12 & 11.72 \\
\hdashline Administrative services & 18.23 & 10.74 \\
\hline Secretariat-general services & 15.92 & 10.85 \\
\hline Pensions & 26.4 & 11.61 \\
\hline Miscellaneous general services & & \\
\hline Grants-in-aid and contributions & &
\end{tabular}

The state's total expenditure comprises developmental and non-developmental expenditures, grants in aid and contributions (see Table 2). They are declining in state from the second period. Total expenditure during the first period was 12.5 per cent. It has observed as 4.88 per cent in the second period. It means the FRBM Act has reduced the expenditure of the state. But the developmental expenditure has increased from 10.28 to 14.93 from the first period to the second period. Developmental expenditure on social services has increased slightly from the first to the second period. Revenue expenditure on economic services has become double over the period of time. Expenditure on social services has increased from 12.44 per cent to 14.51 per cent from the first period to the second period. Expenditure on economic services has increased from 7.37 per cent to 16 per cent from the first period to the second period. In Maharashtra, the non-developmental expenditure was 16.03 per cent in the first period. In the second period, the growth in non-development expenditure is observed as 10 per cent only. The non-development expenditure has declined in the state. The organs of state have increased. Expenditure on organs of state has slightly increased from 12.05 to 14.01 per cent from the first period to the second period. Expenditure on fiscal services was 30.69 per cent. It is observed negatively as 3.5 per cent in the second period. Revenue expenditure on fiscal services has declined very sharply in the state. It is observed as negative CAGR in the second period. The interest payment and services of debt were 14.92 per cent in the first period. In the second period, it is observed as 9.71 per cent. There is a sharp decline in the interest payments and servicing of debt. The state has deficit in budget. The surplus is not generated and therefore the state has to borrow money from different internal and external sources. Therefore, the state has to pay interest on such short- and long-term loans. Most of the times, the loans taken by past government has to convert and pay the interest as well as debt. Such interest payment declined from the first period in the state. Expenditure on administrative services has increased from 10.43 to 13.94 per cent from the first to the second period. The population and urbanization have increased over the period of time. Population of the state in terms of actual numbers is increasing fast. Migration and natural growth rate of population are forcing the state to provide various administrative services to population. Therefore, the revenue expenditure is increasing in the state from the second period. The revenue expenditure on secretariat has increased in the first period. The expenditure on secretariat-general services has not changed much in the state. It was 11.72 per cent. The expenditure on pension was 18.23 per cent in the first period. But it has declined (10.74 per cent) in the second period. Government has stopped the pension scheme for new employees from 2005. Pensions have been stopped due to heavy economic burden in India. Therefore, the state government does not spend on pensions after 2005. But earlier expenditure on pensions was too high for the state. The miscellaneous general services expenditure was 15.92 per cent. In the 
second period, it was observed as 10.85 per cent. The state has reduced the miscellaneous expenditure on general services. A grant in aid and contribution of state has reduced over the period of time. The grants-in-aid and contributions were 26.4 per cent in the first period. It has sharply declined in the second period and it is observed as 10.85 per cent. Government has stopped the grant-in-aid program and allowed privatization. The repayment of loans to center was 11.24 per cent. In the second period, it was observed as only 1.71 per cent. The loans and advances by the state government were 6.92 per cent in the first period. It is only 2.95 per cent in the second period. Development purpose expenditure was 7.15 per cent in the first period. It has become half in the second period. The expenditure on social services was 10.01 per cent in the first period. It has declined to 6.64 per cent from the second period. In the second period, it was observed as 9.42 per cent. The non-development purpose expenditure was only 3 per cent in the first period. In the second period, it is observed as -1.97 per cent.

Table 3. Capital receipts of Maharashtra government (percent)

Source: Compiled based on the RBI data.

\begin{tabular}{l|c:c}
\hline \multicolumn{1}{c|}{ Particulars } & $\begin{array}{c}\text { First } \\
\text { period }\end{array}$ & $\begin{array}{c}\text { Second } \\
\text { period }\end{array}$ \\
\hline Total capital receipts & 16.47 & 16.52 \\
External debt & - & - \\
\hline Internal debt & 30.87 & 0.96 \\
\hdashline Loans and advances from the & -0.22 & 10.42 \\
center & 10.92 & 6.54 \\
\hline Recovery of loans and advances & - & - \\
\hdashline Inter-state settlement & - & - \\
\hdashline Contingency fund & -7.66 & 9.59 \\
\hline Small savings, provident funds, & 10.95 & -2.92 \\
etc. & 12.69 & 14.37 \\
\hline Reserve funds & -222.94 & 32.76 \\
\hline Deposits and advances & -216.29 & 4.71 \\
\hline Suspense and miscellaneous & & \\
\hline Remittances & & \\
\hline
\end{tabular}

Total capital receipts have not changed over the period of time. State government has invested in various capital assets. Such capital assets provide receipts over the period of time. Internal debt has declined very sharply in the state. It is due to the government policy. Government of Maharashtra does not borrow much from internal sources and the reason is that an interest rate is very high. The state government receives grants from the cen- tral government. Therefore, internal borrowing is declining in the state. But the state government started receiving loans and advances from the center. It has started very sharply during the first period. Table 3 shows that total capital receipts have not changed over the period of time. Internal debt was very high in the first period. The CAGR was 30.87 per cent in the first period. But after the FRBM Act, it has observed as 0.96 per cent in the second period. The loans and advances from the center was -0.22 per cent in the first period. After the FRBM Act, the loans and advances increased up to 10.42 per cent. State government had recovery of loans and advances in the past. But recently, the loan recovery and advances have declined. This is mainly because advances have declined in recent periods. Recovery rate of loans has declined. Recovery of the loans and advances was 10.92 per cent in the first period. It has sharply declined in the second period. It is observed as 6.54 per cent. The small savings, provident funds were -7.66 per cent in the first period. It has sharp increased and it is observed as 9.59 per cent in the second period. It has sharp increased and it is observed as 9.59 per cent in the second period. The small savings and provident fund have improved because state government gets receipts from people. The state government has major contributions as provident funds of government officials. They are increasing over the period of time. The reserve funds before the FRBM Act were 10.59 per cent in the first period. But in the second period, it has observed as negative $(-2.95)$ in the second period. The reserve funds are declining in the state. State government does not reserve funds. State government is earning deficit and, therefore, funds are not reserved for future contingencies. The deposits and advances were 12.69 per cent in the first period. In the second period, it has observed as 14.37 per cent. Deposits and advances have shown slight increase because state government started deposits in various time periods. Advances are given over the period of time and therefore they are also increasing. Only small increase in deposits and advances is observed over the period of time. The suspense and miscellaneous was -222.94 per cent during the first period. The suspense and miscellaneous receipts were negative in the first period. But in the second period, they have improved over the period of time. 
In the second period, it is observed as 32.76 per cent. Such suspense and miscellaneous receipts declined sharply in the state. The remittance receipts have declined from -216.29 per cent to 4.71 per cent from the first period to the second period. The remittances are slightly improved by the state. They are seen positive and their contribution is increasing.

Table 4. Capital expenditure of the state government (CAGR) (percent)

Source: Compiled RBI data.

\begin{tabular}{|c|c|c|}
\hline Particulars & $\begin{array}{l}\text { First } \\
\text { period }\end{array}$ & $\begin{array}{l}\text { Second } \\
\text { period }\end{array}$ \\
\hline Total capital disbursements & 9.72 & 18 \\
\hline Total capital outlay & 10.86 & 10.04 \\
\hline Developmental expenditure & 10.94 & 9.47 \\
\hline Social services & 7.16 & 22.38 \\
\hline Economic services & 11.17 & 8.43 \\
\hline $\begin{array}{l}\text { Non-developmental (general } \\
\text { services) expenditure }\end{array}$ & 5.8 & 3.3 \\
\hline Discharge of internal debt & 11.08 & -4.61 \\
\hline Repayment of loans to the center & 11.24 & 1.71 \\
\hline $\begin{array}{l}\text { Loans and advances by state } \\
\text { governments }\end{array}$ & 6.92 & 2.95 \\
\hline $\begin{array}{l}\text { Developmental purposes } \\
\text { expenditure }\end{array}$ & 7.15 & 3.54 \\
\hline Social services expenditure & 10.1 & 6.46 \\
\hline Economic services expenditure & 6.46 & 9.42 \\
\hline Non-developmental purposes & 3 & -1.97 \\
\hline
\end{tabular}

Total capital disbursement during the first period was 9.72 per cent. It became double in the second period. It is observed as 18 per cent. Total capital disbursement has become double in the second period. Total capital disbursement excluding public accounting has declined in the second period. It may perhaps because development capital expenditure and non-development expenditure may be higher. Total capital outlay has not increased from the first (10.86 per cent) to the second (10.04 per cent) period see Table 4 . The development expenditure in the first period was 10.94 per cent. In the second period, it was observed as 9.47 per cent. There is no much change in capital outlay over the period of time. The state has cut development expenditure in the second period. The state cannot spend more on capital intensive projects. The expenditure on non-developmental purpose has declined very sharply in the state. This is because state surplus has declined fast. Therefore, capital expenditure for non-development purpose has automatically declined. The capital expenditure on social services was 7.16 per cent in the first period. It has increased three times (22.38 per cent) in the second period. Capital expenditure for development purposes has declined for the state. Social services expenditure has declined very sharply in the state. The capital expenditure on economic services has increased in the second period. Social services have improved by the state. But the state has sharply reduced the capital expenditure on economic services. It may be because it has no money to invest in economic services. The expenditure on economic services was 11.17 per cent in the first period. It has slightly declined to 8.43 per cent in the second period. The non-development expenditure was 5.8 per cent in the first period. In the second period, it was 3.33 per cent. The non-development expenditure is also reduced by the state over the period of time. Almost half of the non-development expenditure has been reduced by the state in the second period. The discharge of internal debt was 11.08 per cent in the first period. In the second period, it was observed as -4.61 per cent. Loans and advances have also declined very sharply by the state government. The state is not in a good position to repay loans taken from the center. State government is also not in a position to repay internal debt. The discharge of internal debt must be done on a regular basis. But in recent period, state government is not in a position to repay internal debt. The growth rate from repayment has declined very fast for the state.

\section{REGRESSION RESULTS}

In order to study the relationship of different variables with the revenue receipts and expenditure, capital receipts and expenditure, ordinary least square regression model has been used. The regression model is defined as follows:

$Y_{i t}=\alpha+\beta x_{1}+\beta x_{2}+\beta x_{3}+\beta x_{4}+\ldots+\in$,

where $Y_{i t}$ is the dependent variable and it is considered as state's revenue receipts, revenue expenditure, capital receipts and capital expenditure over the period of time. The independent variables are considered as the subhead of each revenue and expenditure. The dummy variable approach is also used to understand the effect of the FRBM Act on revenue receipts, revenue expenditure, capital 
Table 5. Revenue receipts of the state government

\begin{tabular}{|c|c|c|c|c|c|c|c|}
\hline \multirow{2}{*}{ Particulars } & \multirow{2}{*}{$\begin{array}{l}\text { Intercept/ } \\
\text { Slope }\end{array}$} & \multicolumn{3}{|c|}{ First period } & \multicolumn{3}{|c|}{ Second period } \\
\hline & & Coefficients & t-stat & $\mathbf{R}^{2} / \mathbf{A R}^{2}$ & Coefficients & t-stat & $\mathbf{R}^{2} / \mathbf{A R}^{2}$ \\
\hline \multirow{2}{*}{ Total revenue } & Intercept & $-2.48 *(0.39)$ & -6.22 & 0.98 & $5.00 *(0.96)$ & 5.16 & 0.52 \\
\hline & Slope & $0.00 *(0.00)$ & 25.57 & 0.98 & $0.00 *(0.00)$ & 3.46 & 0.47 \\
\hline \multirow{2}{*}{ Tax revenue } & Intercept & $-1.78 * *(0.34)$ & -5.19 & 0.98 & $4.83 *(0.96)$ & 5.00 & 0.54 \\
\hline & Slope & $0.00 *(0.00)$ & 27.71 & 0.98 & $0.00 *(0.00)$ & 3.63 & 0.50 \\
\hline \multirow{2}{*}{ State's own tax revenue } & Intercept & $-1.23 * *(0.41)$ & -2.99 & 0.97 & $4.83 *(0.96)$ & 4.98 & 0.54 \\
\hline & Slope & $0.00\left({ }^{*} 0.00\right)$ & 21.82 & 0.97 & $0.00 * *(0.00)$ & 3.62 & 0.50 \\
\hline \multirow{2}{*}{ Taxes on income } & Intercept & $1.13(0.74)$ & 1.51 & 0.88 & $5.19 *(1.03)$ & 5.04 & 0.45 \\
\hline & Slope & $0.00 *(0.00)$ & 9.12 & 0.87 & $0.00 * *(0.00)$ & 3.00 & 0.40 \\
\hline \multirow{2}{*}{$\begin{array}{l}\text { Taxes on property and capital } \\
\text { transactions }\end{array}$} & Intercept & $0.51(0.39)$ & 1.31 & 0.99 & $4.95 *(0.95)$ & 5.17 & 0.54 \\
\hline & Slope & $0.00 *(0.00)$ & 19.03 & 0.97 & $0.00 *(0.00)$ & 3.57 & 0.49 \\
\hline \multirow{2}{*}{$\begin{array}{l}\text { Taxes on commodities } \\
\text { and services }\end{array}$} & Intercept & $-1.68^{* *}(0.42)$ & -3.98 & 0.97 & $4.78^{*}(0.96)$ & 4.94 & 0.55 \\
\hline & Slope & $0.00 *(0.00)$ & 22.36 & 0.97 & $0.00 *(0.00)$ & 3.66 & 0.51 \\
\hline \multirow{2}{*}{ Share in central taxes } & Intercept & $-3.64 * *(1.95)$ & -1.86 & 0.75 & $5.38^{* *}(1.02)$ & 5.26 & 0.43 \\
\hline & Slope & $0.00 *(0.00)$ & 5.68 & 0.72 & $0.00 * *(0.00)$ & 2.85 & 0.37 \\
\hline \multirow{2}{*}{ Non tax revenue } & Intercept & $-4.58 * *(1.31)$ & -3.48 & 0.89 & $5.58 *(1.00)$ & 5.55 & 0.41 \\
\hline & Slope & $0.00 *(0.00)$ & 9.21 & 0.87 & $0.00 * *(0.00)$ & 2.76 & 0.36 \\
\hline \multirow{2}{*}{ State's own non-tax revenue } & Intercept & $-3.16^{* *}(1.21)$ & -2.59 & 0.88 & $5.75 *(1.02)$ & 5.59 & 0.36 \\
\hline & Slope & $0.00 *(0.00)$ & 8.82 & 0.87 & $0.00^{* *}(0.00)$ & 2.50 & 0.30 \\
\hline \multirow{2}{*}{ Interest receipts } & Intercept & $0.14(1.72)$ & 0.08 & 0.63 & $5.64 *(1.12)$ & 5.01 & 0.30 \\
\hline & Slope & $0.00^{* *}(0.00)$ & 4.32 & 0.59 & $0.00^{* * *}(2.18)$ & 2.18 & 0.23 \\
\hline \multirow{2}{*}{ Dividends and profits } & Intercept & $10.85^{* *}(2.42)$ & 4.47 & 0.22 & $6.47 *(1.11)$ & 5.82 & 0.14 \\
\hline & Slope & $-0.006(0.003)$ & -1.74 & 0.14 & $0.00(0.00)$ & 1.36 & 0.06 \\
\hline \multirow{2}{*}{ General services } & Intercept & $0.41(1.42)$ & 0.29 & 0.70 & $5.87 *(1.01)$ & 5.78 & 0.35 \\
\hline & Slope & $0.0001(0.00)$ & 5.11 & 0.67 & $0.00^{* *}(0.00)$ & 2.45 & 0.29 \\
\hline \multirow{2}{*}{ Social services } & Intercept & $-2.06(0.67)$ & -3.04 & 0.95 & $4.88 *(0.95)$ & 5.09 & 0.54 \\
\hline & Slope & $0.00(0.00)$ & 14.42 & 0.95 & $0.00 *(0.00)$ & 3.62 & 0.50 \\
\hline \multirow{2}{*}{ Economic services } & Intercept & $-5.87(1.27)$ & -4.62 & 0.91 & $5.10 *(0.99)$ & 5.12 & 0.49 \\
\hline & Slope & $0.00(0.00)$ & 10.51 & 0.90 & $0.00 *(0.00)$ & 3.24 & 0.44 \\
\hline \multirow{2}{*}{ Grants from the center } & Intercept & $-6.33(2.92)$ & -2.16 & 0.66 & $5.45^{*}(0.99)$ & 5.48 & 0.44 \\
\hline & Slope & $0.00(0.00)$ & 4.66 & 0.63 & $0.00^{* *}(0.00)$ & 2.95 & 0.39 \\
\hline
\end{tabular}

Note: ${ }^{\star}$ Significant at 1 per cent, ${ }^{* *}$ significant at 5 per cent, ${ }^{* *}$ significant at 10 per cent.

receipts and capital expenditure. The results are presented in Table 5.

Total revenue was statistically significant and positively correlated with revenue receipts in the first period. Tax revenue was negatively correlated in the first period. Such result was significant and negatively correlated with the revenue receipts. But the tax revenue is positively correlated with revenue receipts. Such results are positive and statistically significant. The state's own tax revenue was negatively correlated with revenue receipts in the first period. In the second period, the state's own tax revenue has increased. Such result was positive and statistically significant. The taxes on income were statistically significant and positively correlated in the second period. The taxes on property and capital transactions in the second period were positive and statistically significant. The taxes on commodities and services were negative and statistically significant in the first period. In the second period, taxes on commodities and services were positive and statistically significant. The share in central taxes was negative with respect to revenue receipts. It was statistically significant and positively correlated to revenue receipts in the second period. The non-tax revenue was negatively correlated with revenue receipts in the first period. In the second period, the non-tax revenue was positively correlated and statistically significant with revenue receipts. The state's own non tax revenue was negatively correlated and statistically significant in the first period. In the second period, the state's own non tax revenue was positive and statistically significant. The interest receipts was positively correlated with revenue receipts in the sec- 
Table 6. Regression results for revenue expenditure

\begin{tabular}{|c|c|c|c|c|c|c|c|}
\hline \multirow{2}{*}{ Revenue expenditure } & \multirow{2}{*}{$\begin{array}{l}\text { Intercept/ } \\
\text { Slope }\end{array}$} & \multicolumn{3}{|c|}{ First period } & \multicolumn{3}{|c|}{ Second period } \\
\hline & & Coefficient & t-test & $\mathbf{R}^{2} / \mathbf{A R}^{2}$ & Coefficient & t-test & $\mathbf{R}^{2} / \mathbf{A R}^{2}$ \\
\hline \multirow{2}{*}{ Total expenditure } & Slope & $-0.64(0.51)$ & -1.25 & 0.96 & $-0.47(0.57)$ & -0.82 & 0.94 \\
\hline & Intercept & $0.00 *(0.00)$ & 16.54 & 0.95 & $0.00 *(0.00)$ & 14.40 & 0.94 \\
\hline \multirow{2}{*}{ Developmental expenditure } & Slope & $-2.33^{* *}(0.61)$ & -3.77 & 0.95 & $0.039(0.48)$ & 0.06 & 0.96 \\
\hline & Intercept & $0.00 *(0.00)$ & 16.19 & 0.95 & $0.00 *(0.00)$ & 16.29 & 0.95 \\
\hline \multirow{2}{*}{ Social services } & Slope & $-0.51(0.53)$ & -0.95 & 0.95 & $0.48(0.58)$ & 0.82 & 0.93 \\
\hline & Intercept & $0.00^{*}(0.00)$ & 15.57 & 0.95 & $0.00 *(0.00)$ & 12.75 & 0.93 \\
\hline \multirow{2}{*}{ Economic services } & Slope & $-4.99 * * *(2.01)$ & -2.47 & 0.77 & $0.06(0.91)$ & 0.07 & 0.86 \\
\hline & Intercept & $0.00 *(0.00)$ & 6.17 & 0.75 & $0.00 *(0.00)$ & 8.52 & 0.85 \\
\hline \multirow{2}{*}{$\begin{array}{l}\text { Non-developmental } \\
\text { expenditure (general } \\
\text { services) }\end{array}$} & Slope & $1.15^{* * *}(0.58)$ & 1.97 & 0.92 & $-1.61^{* * *}(0.76)$ & -2.11 & 0.93 \\
\hline & Intercept & $0.00 *(0.00)$ & 11.72 & 0.91 & $0.00 *(0.00)$ & 12.20 & 0.92 \\
\hline \multirow{2}{*}{ Organs of state } & Slope & $-0.05(1.29)$ & -0.04 & 0.76 & $0.80(0.73)$ & 1.10 & 0.89 \\
\hline & Intercept & $0.00 *(0.00)$ & 6.02 & 0.74 & $0.00 *(0.00)$ & 9.72 & 0.88 \\
\hline \multirow{2}{*}{ Fiscal services } & Slope & $3.62 *(0.68)$ & 5.29 & 0.81 & $10.19^{* *}(2.32)$ & 4.38 & 0.17 \\
\hline & Intercept & $0.00(0.00)$ & 6.96 & 0.79 & $0.00(0.00)$ & -1.52 & 0.10 \\
\hline \multirow{2}{*}{$\begin{array}{l}\text { Interest payments } \\
\text { and servicing of debt }\end{array}$} & Slope & $0.32(0.52)$ & 0.61 & 0.95 & $-2.69 * *(0.69)$ & -3.88 & 0.95 \\
\hline & Intercept & $0.00(0.00)$ & 14.53 & 0.94 & $0.00 *(0.00)$ & 14.94 & 0.94 \\
\hline \multirow{2}{*}{ Administrative services } & Slope & $-1.43^{* * *}(0.69)$ & -2.04 & 0.94 & $0.06(0.51)$ & 0.13 & 0.95 \\
\hline & Intercept & $0.00(* 0.00)$ & 13.13 & 0.93 & $0.00 *(0.00)$ & 15.14 & 0.95 \\
\hline \multirow{2}{*}{ Secretariat-general services } & Slope & $1.81(1.31)$ & 1.38 & 0.65 & $-0.20(0.90)$ & -0.22 & 0.87 \\
\hline & Intercept & $0.00^{* *}(0.00)$ & 4.57 & 0.62 & $0.00 *(0.00)$ & 8.80 & 0.86 \\
\hline \multirow{2}{*}{ Pensions } & Slope & $2.40^{* * *}(0.70)$ & 3.38 & 0.85 & $0.89(0.57)$ & 1.56 & 0.93 \\
\hline & Intercept & $0.00^{* *}(0.00)$ & 8.11 & 0.84 & $0.00 *(0.00)$ & 12.32 & 0.92 \\
\hline \multirow{2}{*}{$\begin{array}{l}\text { Miscellaneous general } \\
\text { services }\end{array}$} & Slope & $5.11^{* * *}(1.25)$ & 4.09 & 0.31 & $7.88^{* *}(1.40)$ & 5.62 & 0.08 \\
\hline & Intercept & $0.0003^{* * *}(0.00)$ & 2.25 & 0.25 & $0.00(0.00)$ & -0.99 & -0.00 \\
\hline \multirow{2}{*}{$\begin{array}{l}\text { Grants-in-aid and } \\
\text { contributions }\end{array}$} & Slope & $3.93^{* *}(0.77)$ & 5.04 & 0.74 & $4.12 * *(1.42)$ & 2.89 & 0.37 \\
\hline & Intercept & $0.0001^{* *}(0.00)$ & 5.72 & 0.72 & $0.00^{* *}(0.00)$ & 2.59 & 0.32 \\
\hline
\end{tabular}

Note: ${ }^{\star}$ Significant at 1 per cent, ${ }^{* *}$ significant at 5 per cent, ${ }^{* *}$ significant at 10 per cent.

ond period and it was statistically significant. The dividends and profit of state government was positive in both periods. General receipts were positive and statistically significant in the second period. Social services with revenue receipts were negative in the first period and they were observed as positively correlated in the second period. The economic services to revenue receipts were negative in the first period. It was positive in the second period. The grants from central government were negatively correlated with revenue receipts in the first period. In the second period, they were observed as positively correlated with revenue receipts.

In the revenue expenditure, there are numbers of subheads that are significant and some are not significant (see Table 6). Total expenditure is significant in both periods, that is before the FRBM Act and after the FRBM Act. State has no choice but to continue same spending on various departments, administration and projects in the state. Therefore, expenditure in state budgets is positively correlated and statistically significant. The development expenditure in the first and second periods was statistically significant and positively correlated. The state has to spend on various development related work and projects. The FRBM Act is not affecting such development expenditure. "The role of state is very important in provision of public goods. The provision of public good can help poor people to escape from vicious circle of poverty, undernourishment and underemployment" (Afridi, 2017). The expenditure on social services was positive in period one and period two. Such result is statistically significant and positively correlated. The organs of state were positive and statistically significant in periods one and two. The expenditure on organs of state was positive in both periods. The expenditure on fiscal services was positive in both periods. The interest payment and serving debt was negative in the second period. This is mainly because state has reduced its dependence on loans. The earlier debt 
Table 7. Regression results for capital receipts of the state government

\begin{tabular}{|c|c|c|c|c|c|c|c|}
\hline \multirow{2}{*}{ Particulars } & \multirow{2}{*}{$\begin{array}{l}\text { Intercept// } \\
\text { Slope }\end{array}$} & \multicolumn{3}{|c|}{ First period } & \multicolumn{3}{|c|}{ Second period } \\
\hline & & Coefficients & T-stat & $\mathbf{R}^{2} / \mathbf{A R}^{2}$ & Coefficients & T-stat & $\mathbf{R}^{2} / \mathbf{A R}^{2}$ \\
\hline \multirow{2}{*}{ Total capital receipts } & Intercept & $0.98(0.65)$ & 1.50 & 0.95 & $1.36(0.88)$ & 1.55 & 0.83 \\
\hline & Slope & $0.00(0.00)$ & 7.47 & 0.91 & $0.00 *(0.00)$ & 7.47 & 0.82 \\
\hline \multirow{2}{*}{ Internal debt } & Intercept & $4.47^{* *}(0.76)$ & 5.81 & 0.71 & $0.11(3.92)$ & 0.03 & 0.23 \\
\hline & Slope & $0.00 * *(0.00)$ & 5.27 & 0.69 & $0.00^{* * *}(0.00)$ & 1.81 & 0.16 \\
\hline \multirow{2}{*}{ Recovery of loans and advances } & Intercept & $6.22 *(1.34)$ & 4.63 & 0.07 & $6.66^{* *}(2.06)$ & 3.23 & 0.00 \\
\hline & Slope & $0.00(0.00)$ & 0.97 & -0.00 & $0.00(0.00)$ & 0.19 & -0.08 \\
\hline \multirow{2}{*}{ Small savings, provident funds, etc. } & Intercept & $5.54 *(1.40)$ & 3.94 & 0.17 & $-0.85(0.89)$ & -0.95 & 0.89 \\
\hline & Slope & $0.00 *(0.00)$ & 1.51 & 0.09 & $0.00 *(0.00)$ & 9.58 & 0.88 \\
\hline \multirow{2}{*}{ Reserve funds } & Intercept & $1.36 *(2.00)$ & 0.68 & 0.46 & $7.09 * *(1.42)$ & 4.99 & 0.00 \\
\hline & Slope & $0.00(0.00)$ & 3.08 & 0.41 & $0.00(0.00)$ & -0.11 & -0.08 \\
\hline \multirow{2}{*}{ Deposits and advances } & Intercept & $3.21^{* *}(1.11)$ & 2.87 & 0.62 & $0.11(0.70)$ & 0.15 & 0.91 \\
\hline & Slope & $0.00 *(0.00)$ & 4.29 & 0.59 & $0.00 *(0.00)$ & 10.99 & 0.90 \\
\hline \multirow{2}{*}{ Suspense and miscellaneous } & Intercept & $6.65 *(1.09)$ & 6.08 & 0.11 & $2.47^{* *}(0.82)$ & 3.00 & 0.81 \\
\hline & Slope & $0.00(0.00)$ & 1.22 & 0.03 & $0.00 *(0.00)$ & 6.86 & 0.79 \\
\hline \multirow{2}{*}{ Remittances } & Intercept & $-7.30 * *(1.06)$ & 6.85 & 0.14 & $-6.27 * *(2.10)$ & -2.97 & 0.79 \\
\hline & Slope & $0.00^{* *}(0.00)$ & 1.37 & 0.06 & $0.00 *(0.00)$ & 6.49 & 0.77 \\
\hline
\end{tabular}

Note: ${ }^{\star}$ Significant at 1 per cent, ${ }^{* *}$ significant at 5 per cent, ${ }^{* *}$ significant at 10 per cent.

has also paid by the state. Therefore, fresh loans are not taken by the state. The expenditure on administrative services was positive and statistically significant. State has started spending more on administrative services. People are provided various public goods and services. Therefore, the spending on administrative services has increased. The expenditure on secretariat - general services - has increased. It is statistically significant and positively correlated to the total expenditure of state. The expenditure on pension was significant in the first period, whereas in the second period, it was not significant. In the second period, the pension scheme has been stopped to new employee. Therefore, expenditure on pension has also declined. Expenditure on general services was the same in both periods. Any change or difference in this expenditure has not been found. The grants-in-aid and contributions are statistically significant and positively correlated with total expenditure in both periods. They are least affected by the 2003 FRBM Act. The capital receipts over the two period have been also studied. The results are presented in Table 7.

One never found the total capital receipts as significant in both periods. The state government has very low capital receipts. The internal debt was positively correlated with capital receipts in the first period. In the second period, such relationship has not been found as positive or negative. The recovery of the loan and advances was statistically significant and positively co-related with the total receipts. The small saving provident fund was statistically significant in period one and it was positively correlated to the capital receipts. The reserve funds with capital receipts were positive in the second period. The deposit and advances were positive in the first period. It was positively correlated and statistically significant. The suspense and miscellaneous was positive and statistically significant in both periods. The remittances were negatively correlated and statistically significant in both periods.

Total capital disbursement to capital expenditure in the second period was positive and statistically significant (see Table 8). The total capital disbursement to capital expenditure was negatively correlated. Such relationship is statistical significant. The total capital outlays were negatively correlated and statistically significant with capital expenditure. Developmental expenditure was negatively correlated with capital expenditure and statistically significant. Expenditure on economic services was negative and statistically significant. The non-development expenditure was positively correlated to capital expenditure. The discharge of internal debt was positive and statistically significant in the second period. The repayment of loan was negatively correlated with capital expenditure. But in the second period, it was positive and statistically significant. Advances of state government were positive in both periods. Developmental pur- 
Table 8. Regression results for capital expenditure

\begin{tabular}{|c|c|c|c|c|c|c|c|}
\hline \multirow{2}{*}{ Capital expenditure } & \multirow{2}{*}{$\begin{array}{c}\text { Intercept/ } \\
\text { Slope }\end{array}$} & \multicolumn{3}{|c|}{ First period } & \multicolumn{3}{|c|}{ Second period } \\
\hline & & Coefficients & T-test & $\mathbf{R}^{2} / \mathbf{A R}^{2}$ & Coefficients & T-test & $\mathbf{R}^{2} / \mathbf{A R}^{2}$ \\
\hline \multirow{2}{*}{ Total capital disbursements } & Intercept & $0.27(1.96)$ & 0.14 & 0.55 & $0.22 * *(1.99)$ & 2.08 & 0.75 \\
\hline & Slope & $0.00 * *(0.00)$ & 3.70 & 0.51 & $0.00 *(0.00)$ & 5.76 & 0.73 \\
\hline \multirow{2}{*}{ Total capital disbursements } & Intercept & $0.27(1.96)$ & 0.14 & 0.55 & $-3.82 * *(2.02)$ & -1.88 & 0.74 \\
\hline & Slope & $0.00 * *(0.00)$ & 3.70 & 0.51 & $0.00 *(0.00)$ & 5.57 & 0.71 \\
\hline \multirow{2}{*}{ Total capital outlay } & Intercept & $-0.63(1.71)$ & -0.37 & 0.68 & $-2.28 * * *(1.25)$ & -1.82 & 0.85 \\
\hline & Slope & $0.00 * *(0.00)$ & 4.81 & 0.64 & $0.00 *(0.00)$ & 7.89 & 0.83 \\
\hline \multirow{2}{*}{ Developmental expenditure } & Intercept & $-0.60(1.70)$ & -0.35 & 0.68 & $-2.66^{* *}(1.36)$ & -1.95 & 0.83 \\
\hline & Slope & $0.00 * *(0.00)$ & 4.82 & 0.64 & $0.00 *(0.00)$ & 7.49 & 0.82 \\
\hline \multirow{2}{*}{ Social services } & Intercept & $1.38(2.23)$ & 0.62 & 0.40 & $1.73(1.04)$ & 1.65 & 0.76 \\
\hline & Slope & $0.00 * *(0.00)$ & 2.73 & 0.35 & $0.00 *(0.00)$ & 5.91 & 0.73 \\
\hline \multirow{2}{*}{ Economic services } & Intercept & $-0.35(1.71)$ & -0.21 & 0.66 & $-3.22 * *(1.55)$ & -2.07 & 0.81 \\
\hline & Slope & $0.00 * *(0.00)$ & 4.64 & 0.63 & $0.00 *(0.00)$ & 6.94 & 0.79 \\
\hline \multirow{2}{*}{ Non-developmental expenditure } & Intercept & $1.50(2.51)$ & 0.60 & 0.33 & $3.11 * *(0.74)$ & 4.19 & 0.81 \\
\hline & Intercept & $0.001^{* *}(0.00)$ & 2.35 & 0.27 & $0.00 *(0.00)$ & 6.95 & 0.79 \\
\hline \multirow{2}{*}{ Discharge of internal debt } & Slope & $2.21(1.47)$ & 1.50 & 0.56 & $6.46^{* *}(2.47)$ & 2.61 & 0.00 \\
\hline & Intercept & $0.00^{* *}(0.00)$ & 3.76 & 0.52 & $0.00 *(0.00)$ & 0.24 & -0.09 \\
\hline \multirow{2}{*}{ Repayment of loans to the center } & Slope & $-1.57^{* *}(0.58)$ & -2.70 & 0.96 & $7.94 * *(1.41)$ & 5.62 & 0.08 \\
\hline & Intercept & $0.00 *(0.00)$ & 16.02 & 0.95 & $0.00 *(0.00)$ & -1.03 & 0.01 \\
\hline \multirow{2}{*}{$\begin{array}{l}\text { Loans and advances by state } \\
\text { governments }\end{array}$} & Slope & $6.55 * *(1.50)$ & 4.36 & 0.02 & $11.27 *(1.85)$ & 6.08 & 0.38 \\
\hline & Intercept & $0.00(0.00)$ & 0.44 & -0.07 & $0.00^{* *}(0.00)$ & -2.62 & 0.33 \\
\hline \multirow{2}{*}{ Developmental purposes } & Slope & $0.05(2.20)$ & 0.02 & 0.51 & $10.96 *(1.84)$ & 5.93 & 0.36 \\
\hline & Intercept & $0.00 * *(0.00)$ & 3.38 & 0.46 & $0.00^{* *}(0.00)$ & -2.46 & 0.29 \\
\hline \multirow{2}{*}{ Social services } & Slope & $-3.10^{* * *(1.71)}$ & -1.82 & 0.77 & $-0.04(3.58)$ & -0.01 & 0.27 \\
\hline & Intercept & $0.00 *(0.00)$ & 6.21 & 0.76 & $0.00^{* *}(0.00)$ & 2.03 & 0.21 \\
\hline \multirow{2}{*}{ Economic services } & Slope & $1.80(2.21)$ & 0.82 & 0.37 & $9.90 *(1.33)$ & 7.39 & 0.42 \\
\hline & Intercept & $0.00 * *(0.00)$ & 2.57 & 0.32 & $0.00^{* *}(0.00)$ & -2.82 & 0.37 \\
\hline \multirow{2}{*}{ Non-developmental purposes } & Slope & $6.99(1.11)$ & 6.25 & 0.02 & $8.11 * *(1.44)$ & 5.63 & 0.10 \\
\hline & Intercept & $0.00(0.00)$ & -0.44 & -0.07 & $-0.00(0.00)$ & -1.15 & 0.03 \\
\hline
\end{tabular}

Note: ${ }^{\star}$ Significant at 1 per cent, ${ }^{* *}$ significant at 5 per cent, ${ }^{* *}$ significant at 10 per cent.

pose expenditure was statistically significant and positive in the second period. Social services capital expenditure in the first period was positive and statistically significant. Economic services in the second period are positive and statistically significant. The non-development expenditure was positive and statistically significant in the second period. Citizens residing in countries with lower provisions of government goods and services will receive higher returns from additional government spending rather than citizens in countries with already high levels of government provisions. As a result, citizens in the former countries will have more willingness to pay for additional government goods and services than those in the latter countries. This could lead countries with less government expenditure to increase their expenditure more than the countries with high level of government expenditure. Hence convergence in public expenditure could take place (Garg, 2015).

\subsection{Ordinary least square regression results}

Ordinary least square regression has been used to examine the relation between dependent variable and independent variable. The results are presented in Table 9.

The stamp and registration fees are positively correlated with revenue receipts in the state. The sales tax on motor sprit and lubricants is positively correlated to the revenue receipts in the state. The entertainment tax is negatively correlated with revenue receipts. It is statistically significant and positively correlated with revenue receipts. Other taxes and duties are positively correlated with revenue receipts in the state. The dividends and profits are positively corelated and statistically significant. Other taxes and duties are positively correlated and statistically significant. The dividends and 
profit are positively correlated and statistically significant. The major and minor irrigation projects are negatively correlated with revenue receipts in the state. Irrigation projects are important national assets, created by pumping in huge investments, whose benefits cannot be evaluated in terms of direct financial returns. They generate social benefits in the form of better health and hygienic standards, better habitats, etc., culminating in overall better standards of life, particularly in neglected rural communities, leading to higher productivity of water and land and human resources. Based on the area irrigated, these irrigation projects have been classified by the Central Government as major, medium and minor (Mohanty \& Patra, 2016).

Table 9. Regression results for revenue receipts

\begin{tabular}{|c|c|c|}
\hline Variables & Coefficient & T-test \\
\hline Constant & $238520^{* *}(696)$ & 3.42 \\
\hline $\begin{array}{l}\text { Stamps and registration } \\
\text { fees }\end{array}$ & $6.63 *(0.55)$ & 11.90 \\
\hline $\begin{array}{l}\text { Sales tax on motor spirit } \\
\text { and lubricants }\end{array}$ & $1.19 *(0.16)$ & 7.11 \\
\hline Entertainment tax & $-33.90 *(3.37)$ & -10.05 \\
\hline Other taxes and duties & $2.92 *(0.34)$ & 8.74 \\
\hline Dividends and profits & $178.31 *(19.97)$ & 8.92 \\
\hline Others & $86.28 *(9.54)$ & 9.04 \\
\hline $\begin{array}{l}\text { Major and medium } \\
\text { irrigation projects }\end{array}$ & $-48.95 *(6.88)$ & -7.11 \\
\hline Minor irrigation & $132.68 *(31.64)$ & 4.19 \\
\hline Power & $-21.30 *(2.68)$ & -7.94 \\
\hline State plan schemes & $4.68 *(0.54)$ & 8.66 \\
\hline Center plan schemes & $41.72 *(5.73)$ & 7.27 \\
\hline $\begin{array}{l}\text { Centrally sponsored } \\
\text { schemes }\end{array}$ & $4.90 *(0.44)$ & 11.13 \\
\hline Others & $2.73 *(0.30)$ & 8.92 \\
\hline Dummy variables & $264847 * *(70944)$ & 3.73 \\
\hline $\begin{array}{l}\mathrm{R}^{2}=1.00 \mathrm{AR}^{2}=1.00 \\
\text { Std. error of } \\
\text { estimate }=52514.67\end{array}$ & & $F=11501.94$ \\
\hline
\end{tabular}

Note: ${ }^{\star}$ Significant at 1 per cent, ${ }^{* *}$ significant at 5 per cent, $* * *$ significant at 10 per cent.

Major and medium irrigation projects are not undertaken in the state and the relationship is statistically significant and positively correlated.

The minor irrigation is positively correlated and statistically significant with revenue receipts. The power receipts are negatively correlated to the revenue receipts in the state. State government is providing power subsidies. The state plan schemes are positively correlated to the revenue receipts. It is statistically significant.
The central plan schemes are positively correlated with revenue receipts. The centrally sponsored schemes are positively correlated and statistically significant. The dummy variables are statistically significant and positively correlated with revenue receipts. It means the state has positive revenue receipts in the second period as compared to the first period.

Table 10. Regression results for revenue expenditure

\begin{tabular}{|c|c|c|}
\hline Variables & Coefficient & T-test \\
\hline Constants & $-88891.90(108618)$ & -0.81 \\
\hline Labor and labour welfare & $-25.93^{* * *}(9.01)$ & -2.87 \\
\hline $\begin{array}{l}\text { Soil and water } \\
\text { conservation }\end{array}$ & $-43.18^{* *}(10.67)$ & -4.04 \\
\hline Fisheries & $167.02 *(12.74)$ & 13.10 \\
\hline $\begin{array}{l}\text { Science, technology and } \\
\text { environment }\end{array}$ & $-112.75(58.86)$ & -1.91 \\
\hline Organs of state & $26.47^{* *}(2.29)$ & 11.52 \\
\hline $\begin{array}{l}\text { Appropriation for } \\
\text { reduction or avoidance } \\
\text { of debt }\end{array}$ & $5.67^{* *}(1.62)$ & 3.49 \\
\hline District administration & $3.84^{* *}(0.49)$ & 7.70 \\
\hline Police & $10.35^{* * *}(2.32)$ & 4.45 \\
\hline Pensions & $4.92 * * *(1.30)$ & 3.77 \\
\hline Dummy variable & $2.60 * * *(0.98)$ & 2.63 \\
\hline \multicolumn{2}{|c|}{$\begin{array}{l}R^{2}=1.00 A R^{2}=0.99, S t d . \text { error } \\
\text { of estimate }=129137.94\end{array}$} & $F=4740.81$ \\
\hline
\end{tabular}

Note: ${ }^{\star}$ Significant at 1 per cent, ${ }^{*}$ significant at 5 per cent, ${ }^{* * *}$ significant at 10 per cent.

Labour and labour welfare is negatively correlated with revenue expenditure. State government is spending less for labor and labor welfare. The soil and water conservation is statistically significant and negatively correlated to the revenue expenditure. The fisheries are positively correlated to revenue receipts. It is statistically significant and positively correlated. The science, technology and environment are negatively correlated and statistically significant in the state. The state is not spending much on science, technology and environment (see Table 10).

The organs of state are positive and statistically significant in the state. An appropriation for reduction or avoidance of debt was positively correlated with revenue expenditure in the state. The district administration is positively correlated with revenue expenditure. Such expenditure is continuously increasing in the state. 
Expenditure on police is positively correlated and statistically significant. State government is giving much importance to law and order situation in the state. Good law and order situation is related to day to day life of people in the state. The expenditure on pensions is positively correlated with revenue expenditure and statistically significant. State government cannot control expenditure on pensions. It was the earlier staff served to state. Therefore, pension payment is an important aspect of state finances. It cannot be discontinued at any point of time. The dummy variable is positive and statistically significant with revenue expenditure. It means the state is spending more on pensions.

Table 11. Regression results for capital receipts

\begin{tabular}{|c|c|c|}
\hline Variables & Coefficient & T-test \\
\hline Constants & $2342724(350240)$ & 6.68 \\
\hline Urban development & $-1130.89 *(101.18)$ & -11.17 \\
\hline $\begin{array}{l}\text { Village and small } \\
\text { industries }\end{array}$ & $-37317^{*}(6257)$ & -5.96 \\
\hline $\begin{array}{l}\text { Industries and } \\
\text { minerals }\end{array}$ & $67.81^{* *}(19.29)$ & 3.51 \\
\hline Others & $7.71 *(0.84)$ & 9.09 \\
\hline Civil deposits & $8.71 *(0.63)$ & 13.83 \\
\hline Civil advances & $267.97 * *(31.79)$ & 8.42 \\
\hline Suspense & $-10.71 *(1.04)$ & -10.23 \\
\hline Others & $2.37 *(0.15)$ & 15.21 \\
\hline Remittances & $21.11 *(1.55)$ & 13.55 \\
\hline Dummy variable & $-31295595 *(1824577)$ & -17.15 \\
\hline \multicolumn{2}{|c|}{$\begin{array}{l}R^{2}=0.99 A^{R} 2=0.998, \text { Std. error } \\
\text { of estimate }=682654.96\end{array}$} & $F=1387.76$ \\
\hline
\end{tabular}

Note: ${ }^{*}$ Significant at 1 per cent, ${ }^{*}$ significant at 5 per cent, ${ }^{* * *}$ significant at 10 per cent.

The urban development is negatively correlated with the capital receipts. Urban development does not give revenue to the state. The receipts from villages and small industries are negatively correlated to capital receipts. The receipts of civil deposits are positively correlated with capital receipts. The receipts of civil advances are positively correlated with capital receipts in the state. The suspense is positive and statistically significant. Suspense is negatively correlated with capital receipts. They do not add to capital receipts. Remittances are positively correlated with capital receipts. The dummy variable is negatively correlated with capital receipts. It means capital receipt has not improved in the second period (see Table 11).
Table 12. Regression for capital expenditure

\begin{tabular}{|c|c|c|}
\hline Variables & Coefficient & T-test \\
\hline Constant & $541199.21(312729)$ & 1.73 \\
\hline $\begin{array}{l}\text { Education, sports, art } \\
\text { and culture }\end{array}$ & $-1140.92 *(38.17)$ & -29.88 \\
\hline $\begin{array}{l}\text { Medical and public } \\
\text { health }\end{array}$ & $-269.10 *(22.12)$ & -12.16 \\
\hline Others & $2119.13 *(44.11)$ & 48.03 \\
\hline Forestry and wild life & $391.50 * *(72.45)$ & 5.40 \\
\hline $\begin{array}{l}\text { Food storage and } \\
\text { warehousing }\end{array}$ & $48.49^{* *}(8.46)$ & 5.72 \\
\hline $\begin{array}{l}\text { Agricultural research } \\
\text { and education }\end{array}$ & $6378.84 *(247.29)$ & 25.79 \\
\hline Cooperation & $83.06^{* * *(22.25)}$ & 3.73 \\
\hline Others & $1839.04 *(58.29)$ & 31.54 \\
\hline $\begin{array}{l}\text { Loans from National } \\
\text { Cooperative } \\
\text { Development } \\
\text { Corporation }\end{array}$ & $-296.96 *(24.87)$ & -11.93 \\
\hline Housing & $-198.03 *(25.94)$ & -7.63 \\
\hline \multicolumn{2}{|l|}{$\begin{array}{l}\text { Dummy variable } \\
3865360.95 *(520755)\end{array}$} & 7.42 \\
\hline \multicolumn{2}{|c|}{$\begin{array}{l}\mathrm{R}^{2}=0.99 \mathrm{AR}^{2}=0.99, \text { Std. error of } \\
\text { estimate }=551847.04\end{array}$} & $F=2501.90$ \\
\hline
\end{tabular}

Note: ${ }^{\star}$ Significant at 1 per cent, ${ }^{* \star}$ significant at 5 per cent, $* * *$ significant at 10 per cent.

Capital expenditure is negatively correlated with expenditure on education, sports, arts and culture. The expenditure on medical and public health is negatively correlated with capital expenditure over the period of time. The expenditure on others is positively correlated with capital expenditure. The expenditure on forestry and wild life is positively correlated and statistically significant with capital expenditure. The food storage and warehousing is positively correlated with capital expenditure. Co-operation is positively correlated to capital expenditure. Loan from National Co-operative Development Corporation is negatively correlated to capital expenditure. It is statistically significant. The housing expenditure is negatively correlated to the capital expenditure. It is statistically significant. The dummy variable is positive and statistically significant. It means capital expenditure has increased more in the state in the second period as compare to the first period (see Table 12).

\subsection{Debt burden on the state}

State government of Maharashtra has more than Rs. 4 lakh crore public debts at the end of March 2018. The fiscal indicators as presented in Table 1 is deteriorating in recent years. Revenue receipts are not increasing in state due to number of reasons such as cancelled local tax, relaxation of toll tax on some 
roads, subsidy for electricity bills. After demonetization, the stamp duty and registration fees have been declined in the state. Similarly, excise duty on liquor and land tax has been reduced to some extent. Therefore, revenue deficit is observed as Rs3644 crore in 2016-2017. The year was observed as drought like situation in some parts of the state. Similarly, unseasonal rainfall is also observed in some parts of the state. Such rains resulted into loss of crop. State government made some money available for disaster management. State government has raised loan to increase efficiency and financial capacity of units such as Mahavitaran (Rs.4560 crore), major and minor 26 irrigation project (Rs.12773 crore), Rs.30000 crore for construction of ten thousand of new roads. Government paid Rs. 28830 crore interest on borrowings. Therefore, interest payment in 2017-2018 was estimated as Rs31027 crore. Finance minister presented farmers friendly budget where a number of announcements were done under water resource development for Jal youkta Shivar, digging wells and farm ponds, etc. The minister also announced a number of infrastructure projects in the state, such as Samruddhi express, the road project between Mumbai and Nagpur, Chatrapati Shivaji Maharaja Statue in Arabian Sea, etc. All projects and schemes put more pressure on public finance of the state and it worsened fiscal deficit of the state in the current year.

\subsection{Policy implication}

Study shows that there is no much significant difference in revenue, primary and budgetary deficit in the state. But the fiscal deficit is increasing in the state. The total revenue receipts in the state have increased after the FRBM Act. The tax revenue of state government has increased in the 2002-2012 period. The grants from the center have increased thrice in 2002-2012. As far as revenue expenditure is concerned, then total expenditure of the state has declined after the FRBM Act. Expenditure on economic services has increased in the state since 2002-2012. Expenditure on fiscal services has reduced significantly in the state and there was found negatively correlated expenditure. Interest payments and servicing of debt have reduced by the state after the FRBM Act.

Capital receipts are concerned, then interest debt has declined very sharply after the FRBM Act. But the loans and advances from the center increased more than ten per cent after the post FRBM period. The small savings, provident funds have increased in same rate as loans and advances from the center. The reserve funds have declined in the state after the FRBM Act. State has no money to keep in reserve funds. As far as capital expenditure of state government is concerned, total disbursement have become double from first to second period. The capital expenditure as social expenditure has increased thrice from the first to the second period. But the state has reduced the capital expenditure on social services. The capital expenditure by the state on development purposes has reduced to half in period two. The ordinary least square regression results show that the total revenue expenditure in the first period is positively correlated with non-developmental expenditure, fiscal services, pensions, miscellaneous, general services and grant-in-aids and contributions. Revenue expenditure is negatively correlated to developmental expenditure, economic services and administrative services. In the second period, the revenue expenditure is positively correlated to fiscal services, miscellaneous services and grants in aids and contributions. The revenue expenditure is negatively correlated to non-developmental expenditure, interest payments and servicing of debt. In the first period, the revenue receipts are negatively correlated to tax revenue, state own tax revenue, taxes on commodities and services and share in central taxes, non-tax revenue, state social services, economic services and grants from the center. It is positively correlated to dividends and profits. In the second period, the revenue receipts are positively correlated to total revenue, tax revenue, own tax revenue, taxes on commodities and services, share in central taxes, non-tax revenue, state own non tax revenue, interest receipts, dividends and profits, general, social and economic services and grants from the center. The capital receipts are negatively correlated to remittances. The capital receipts are positively correlated to internal debt recovery of loans and advances, small savings, provident funds, reserve funds, deposits and advances, suspense and miscellaneous.

In the second period, capital receipts are negatively correlated to remittances. They are positively correlated to recovery of loans and advances, reserve funds, suspense and miscellaneous. The cap- 
ital expenditure in the first period was positively correlated to loans and advances by state governments and non-development purposes. In the second period, it is negatively correlated to total capital disbursement, total capital outlay, development expenditure and economic services. It is positively correlated to non-development expenditure, discharge of internal debt, repayments of loans to the center, loans and advances by state government, development purpose expenditure, economic services and non-development purposes. The first and the second periods of revenue receipts have been compared. Revenue receipts are found to be positively correlated to stamps and registration fees, other taxes and duties, dividends and profits, others, minor irrigations, state plan schemes, center plan schemes, centrally sponsored schemes and the second period of dummy variable. The revenue receipts are negatively correlated to entertainment tax, major and medium irrigation projects powers. Revenue expenditure is positively correlated to fisheries, organs of state, appropriation for reduction district administration, police force, pensions and dummy variable. The revenue expenditure is negatively correlated to labor and labor welfare, soil and water conservation, science, technology and environment. Capital receipts are positively correlated to industries and minerals, civil deposits, civil advances and remittances. Capital receipts are negatively correlated to urban development, village and small industries, suspense and dummy variable. The capital expenditure is negatively correlated to education, sports, arts and culture, medicine and public health loans from national co-operative, development co-operation and housing. The capital expenditure is positively correlated to forestry and wild life. There are number of alternative policies required for investment and reducing various deficits in the state. The resources are limited with the state. The state government has the responsibility to prioritize the allocation of public expenditure to ensure its best use. This requires taking into consideration not only economic and wider development objectives, but also how these fit to the needs of constituencies (Dickenson et al., 2015). A number of policies have been suggested to increase receipts and investment in the state. State government must increase entertainment tax. All over state, numbers of movies are released every week. Numbers of cultural festivals, programs, parties are arranged regularly. State must impose higher enter tainment tax on such events and programs. Rich people can pay high entertainment tax in the state. State government must invest more funds in soil, water conservation and medium irrigation projects. Investment in soil and water conservation can change the standard of living of farmers. They can produce more crops and export quality agricultural commodities. Such investments can double the income of farmers in the state. The state can take long-term loans and invest in major and minor irrigation projects. In the state, $24^{\star} 7$ electricity is not still provided in urban and rural areas. It affects production in agricultural, manufacturing and services in the state. The state government must invest in the power projects. There are clean energy technologies available, such as wind, solar, tidal, etc. The state government must allow privatization in energy production and such action of the state will help private investors to generate more electricity at cheaper rate. The state must be self-sufficient on electricity production. This will contribute to more economic growth. State government must provide more funds for innovations, science and technology. The state must utilize the young generation talent with technology for future economic development. New technology will help to bring innovations in all the fields in the state. Almost half of the state is urbanized and still urbanization is growing at fast rate. Urbanization is an internal part of globalization. It will increase with the increase in a number of problems. State must invest more in housing, sanitation, water supply, solid waste collection, transport, etc. High investment in such sectors will boost sustainable urbanization. State must spend more on affordable housing. After demonetization, poor people cannot spend more money on registration and stamp duty for house. State government must spend money on affordable housing. It will reduce the number of slums in the state. State must spend money on quality education and give more priority for higher and technical education. The job oriented education is immediately required in the state. Investment in education always yields good returns in the long term. State must spend more resources on health care. The priority must be given for eradication of complete poverty and malnutrition. Modern health infrastructure must be established. The skilled health staff must be appointed on a regular 
basis. State government must increase its revenue through taxes on electronic and tobacco-related products. New sources of taxes must be innovated. Taxes must be increased on commercial vehicles, luxury hotels, entry tax at hill stations, malls and purchase of diamonds and gold, petrol and diesel. For controlling expenditure, state must adopt variety of tasks. The salaries, like non-salary costs, must be subject to the normal rigors of public expenditure management and fiscal discipline - the security sector wage bill must remain affordable (William Byrd \& Stéphane Guimbert, 2009). There are different studies on the pattern of public expenditure. Few state governments are allowing privatization of various infrastructure services. The government enforces contracts made by private parties but each government is sovereign and cannot commit a subsequent government through it can make change difficult (Stiglitz, 2002). All the policies will help to reduce the revenue, fiscal deficit of the state and improve the financial condition of the state.

\section{ACKNOWLEDGEMENT}

The author would like to thank Dr. Abhay Pethe, Professor, Department of Economics, Mumbai University for meaningful insight about the public finance issues in Maharashtra. The author has also benefited the number of lecture series at National Institute for Public Finance and Policy (NIPFP), New Delhi. The major inspiration of writing of this paper is taken from Dr. Lekha and Dr. Pinaki Chakraborty, Professor at NIPFP, New Delhi, India.

\section{REFERENCES}

1. Agbonkhese, A. O., \& Asekome, M. O. (2014). Impact of public expenditure on the growth of Nigerian Economy. European Scientific Journal, 10(28), 219-229. Retrieved from https://eujournal. org/index.php/esj/article/view/4397

2. Ayumi Konishi (2014). Local public finance management in the People's Republic of China: Challenges and opportunities. Asian Development Bank, Metro Manila, Philippines.

3. Chakraborty, Lekha, \& Abhishek Anand (2016). Engendering intergovernmental transfers: Is there a case for gender-sensitive horizontal fiscal equalisation? (Policy research paper). Levy Economics institute, New York

4. Chakraborty, Pinaki (2017). Federalism, Fiscal space and public investment spending: Do fiscal rules impose hard budget constrainst? (ADBI Working Paper 637). Tokyo, Japan.

5. Farzana Afridi (2017, April). Governance and public service delivery in India (Synthesis paper Indian Statistical Institute Economics and Planning Unit 7). S.J.S. Sansanwal Marg, New Delhi-110016, India.
6. Giles Dickenson-Jones, S. Kanay De, \& Andrea Smurra (2015 September). State and Region Public Finances in Myanmar (Subnational governance in Myanmar discussion paper series).

7. Greene, W. (2003). Econometric Analysis (5th ed.). Pearson Education, Private Ltd, Indian Branch, Delhi, India.

8. Mohanty, A. R., \& Patra, S. K. (2016). Impact of Non-Tax Revenue on Revenue Expenditure in Sub-National Public Finance in Economic Sector. IOSR Journal of Economics and Finance, 7(5), 47-62.

9. Pethe, A., \& Lalvani, M. (2005, March). Fiscal Situation in Maharashtra: An assessment, a critique and some policy suggestions (Working paper no. 28). National Institute of Public Finance and Policy, Satsang Vihar Marg, Special Institutional Area, New Delhi-110067.

10. Ratna Vadra (2012). The Indian Economy: Dealing with Public Finance Deficits. Journal of Case Research, 3(02), 125-145. Retrieved from https://www.xub.edu.in/jcr/ cases/IndianEconomy.pdf
11. Reserve Bank of India (2018, July). State finances: A study of budgets of 2017-18 and 2018-19. Published by Reserve Bank of India, Mumbai 400001.

12. Sandhya Garg (2015). Spatial Convergence in Public Expenditure across Indian States: Implication of Federal Transfers. Indira Gandhi Institute of Development Research, Mumbai, December 2015, WP2015-028.

13. Stiglitz Joseph (2002). New perspective on public finance: recent achievements and future challenges. Journal of Public Economics, 86(1), 341-360. https://doi.org/10.7916/ D84B3B57

14. William Byrd \& Stéphane Guimbert (2009, January). Public Finance, Security, and Development: A Framework and an Application to Afghanistan (The World Bank' Policy Research Working Paper 4806). South Asia Region, Poverty Reduction, Economic Management, Finance and Private Sector Development Department, 2009. 